\title{
Evaluation of the autologous conditioned serum in the treatment of osteoarthritis
}

\section{Osteoartrit tedavisinde otolog zenginleştirilmiş serumun değerlendirilmesi}

\author{
Bekir Eray Kılınç ${ }^{1}$, Yunus Öç ${ }^{2}$
}

\section{Abstract}

Aim: The present study was a retrospective study aiming to determine the effect of the autologous conditioned serum (ACS) on osteoarthritis (OA); we made this analysis by injecting it to a symmetrically involved knee.

Methods: The present study comprised 33 patients (19 females, 14 males) with 66 knees and a mean age of 57.6 \pm 8.21 (range: 41-70). The patients included in the study had radiologically verified bilateral grade 2-3 OA of the knee according to Kellgren-Lawrence classification. Secondary arthritis, inflammatory joint diseases, clinically relevant hematologic or abnormal clinical chemistry values, joint instability, intra-articular corticosteroid injection within the previous 6 months, history of diabetes mellitus and body mass index greater than $30 \mathrm{~kg} / \mathrm{m} 2$ were the exclusion criteria. Patients who had VAS difference more than 2 points between their knees were excluded from the study. ACS was injected twice a week for a total of 6 times in both knee joints for 3 weeks. The patients were analyzed with the Visual Analog Scale (VAS) (no pain was graded 0 and maxima pain was graded 10), the Knee Injury and Osteoarthritis Score (KOOS) (scoring ranges between 0 and 100. 0 indicates abnormally high level of knee problems, while 100 indicates a healthy knee with no problems) and the Knee Society Score (KSS) (Of the maximum 100 points, a possible 50 points are assigned to pain, 25 points to stability, and 25 points for range of motion) before the administration of the first injection and again 1 year after the last injection.

Results: The pre-treatment and 1-year follow-up VAS values of the patients were $7.36 \pm 0.93$ (range: 5-9) and $3.27 \pm 1.23$ (range: 1-6), respectively. ACS treatment showed a statistically significant decrease in VAS score (p $<0.01$ ). Pre-treatment and 1-year follow-up KOOS values of the patients were $42.39 \pm 13.38$ (range: $21-65$ ) and $72.36 \pm 8.81$ (range: $54-92$ ), respectively. There was a statistically significant increase in the KOOS values of the patients $(\mathrm{p}<0.01$ ). The pre-treatment and 1-year follow-up KSS values of the patients were $42.79 \pm 10.26$ (range: 14-61) and 70.61 \pm 9.32 (range: 49-84), respectively. There was a statistically significant increase in the KSS values of the patients $(\mathrm{p}<0.01)$.

Conclusion: Use of intra-articular injection of ACS in patients with painful OA leads to significant improvements in pain severity, KOOS and KSS scores. In the light of these findings, ACS treatment may be considered as an effective and safe alternative treatment method in osteoarthritis.

Keywords: Intra-articular injection, autologous conditioned serum, knee osteoarthritis

Öz

Amaç: Çalı̧̧mamızda retrospektif olarak otolog zenginleştirilmiş serum (OZS) tedavisinin osteoartrittek etkisinin bilateral diz enjeksiyonu ile değerlendirilmesi amaçlanmıştır.

Yöntemler: Çalışmamıza yaş ortalaması $57.6 \pm 8.21$ yıl (41-70) olan 33 hasta (19 kadın, 14 erkek) 66 diz dahil edilmiştir. Çalışmamıza katılan hastaların diz osteoartritleri Kellgren-Lawrence sınıflamasına göre bilateral olarak evre 2-3 idi. Sekonder artrit, enflamatuar eklem hastalıkları, klinik olarak ilgili hematolojik veya anorma klinik kimya değerleri, eklem instabilitesi, son 6 ay içerisinde eklem içi kortikosteroid enjeksiyonu uygulanan, diabetes mellitus öyküsü, $30 \mathrm{~kg} / \mathrm{m} 2$ 'dan büyük vücut kitle indeksi mevcut olan hastalar çalışmadan dışlandı. Her iki diz arasındaki VAS farklılığı 2 puandan fazla olan hastalar çalışmadan çıkarıldı. Üç hafta boyunca haftada iki kez toplamda $6 \mathrm{kez} \mathrm{her} \mathrm{iki} \mathrm{diz} \mathrm{eklem} \mathrm{içine} \mathrm{OZS} \mathrm{enjekte} \mathrm{edildi.} \mathrm{Hastalar} \mathrm{VAS} \mathrm{ağrı} \mathrm{skorlaması} \mathrm{(hiç} \mathrm{ağrı} \mathrm{olmaması}$ 0 olarak ve maksimum ağrı 10 olarak derecelendirildi), Diz Yaralanması ve Osteoartirit Skalası (DYOS) (puanlama 0 ile 100 arasında değişmektedir. 0 anormal derecede yüksek diz problemleri gösterirken, 100 problemsiz sağlıklı bir diz göstermektedir) ve Diz Cemiyeti Skorlaması (DCS) (Maksimum 100 puan olan skala ağrıya 50 , stabiliteye 25 ve eklem hareket açıklı̆gna 25 puan atanır) skalaları ile ilk enjeksiyon öncesi ve son enjeksiyondan 1 yil sonra değerlendirildi.

Bulgular: Hastaların tedavi öncesi ve 1. yıl takip VAS değerleri sırası ile $7.36 \pm 0.93$ (aralık: 5-9) ve $3.27 \pm 1.23$ (aralık: 1-6) idi. OZS tedavisi VAS skorunda istatistiksel olarak anlamlı düşme göstermiştir $(\mathrm{p}<0.01)$. Hastaların tedavi öncesi ve 1. yıl takip DYOS toplam değerleri sırası ile 42.39 \pm 13.38 (aralık: $21-65$ ) ve $72.36 \pm 8.81$ (aralık: 54-92) idi. Hastaların DYOS total skorunda istatistiksel olarak anlamlı yükselme saptanmıştır $(\mathrm{p}<0.01)$ Hastaların tedavi öncesi ve 1. yıl takip DCS değerleri sırası ile 42.79 \pm 10.26 (aralık: 14-61) ve $70.61 \pm 9.32$ (aralık: 49-84) idi. Hastaların DCS değerlerinde istatistiksel olarak anlamlı yükselme saptanmıştır $(\mathrm{p}<0.01)$.

Sonuç: Ağrılı diz osteoartriti olan hastalarda inra-artiküler OZS kullanımı ağrı şiddeti, DYOS ve DCS skorları açısından anlamlı iyileşmelere yol açmaktadır. Bu bulgular ışı̆̆ında, OZS tedavisi osteoartritte etkili ve güvenli bir alternatif bir tedavi yöntemi olarak değerlendirilebilir.
${ }^{1}$ University of Health Sciences, Fatih Sultan Mehmet Education and Research Hospital, Department of Orthopaedics and Traumatology, İstanbul, Turkey.

${ }^{2}$ Medilife Hospital, Clinic of Orthopaedics and Traumatology, İstanbul, Turkey.

Conflict of Interest: No conflict of interest was declared by the authors.

Cıkar Catışması: Yazarlar çıkar çatıșması bildirmemişlerdir.

Financial Disclosure: The authors declared that this study has received no financial support.

Finansal Destek: Yazarlar bu çalışma için finansal destek almadıklarını beyan etmişlerdir.

Gelis Tarihi / Received: 24.05.2019

Kabul Tarihi / Accepted: 20.07.2019

Yayın Tarihi / Published: 01.08.2019

Sorumlu yazar / Corresponding author:

Bekir Eray Kılınç

Adres/Address: University of Health Sciences, Fatih Sultan Mehmet Education and Research Hospital, Department of Orthopaedics and Traumatology, İstanbul, Turkey. e-posta: dreraykilinc@gmail.com Tel/Phone: +905306061884

\section{Copyright $($ ACEM}




\section{Introduction}

Osteoarthritis (OA) is the most important cause of locomotor disability in Western societies and a major issue on their healthcare systems $[1,2]$. It is a progressive and chronic condition leading to pain and loss of function that dramatically reduces patients' quality of life and ability to work. It is the most common type and encountered in $6 \%$ of adults, with a prevalence reaching up to $40 \%$ in advanced age cases (>70 years) [3]. The management of the knee OA begins with conservative treatment such as physical therapy, exercise, weight loss and medications. Pharmacologic treatment options for OA used to be restricted to the symptomatic use of analgesics, non-steroidal antiinflammatory drugs (NSAIDs) and the intra-articular injection of steroids or hyaluronan (HA) [4]. Intra-articular HA is commonly used as a safe, off-the shelf treatment for OA of the knee, but its efficacy is controversial. There is a pressing need for novel, improved, mechanism-based agents for treating OA. Surgical intervention can be indicated for patients with advanced OA [5].

In $\mathrm{OA}$, the destruction of hyaline cartilage constitutes the central pathological mechanism causing various mechanical and biological dysfunctions within the joint. Of the cytokines identified in osteoarthritic joints, interleukin-1 (IL-1) appears to be of particular importance. Accordingly, the IL-1 receptor antagonist protein (IRAP), a naturally occurring inhibitor of IL1 , has been reported to limit the intra-articular damage associated with IL-1 [4, 5]. In animal models, many researchers have succeeded in positively modifying the osteoarthritic disease process by effectively antagonizing IL-1 [4-7]. Autologous conditioned serum (ACS) is an example of a presumably diseasemodifying treatment for OA based on antagonizing the intraarticular effects of IL-1 [6, 7]. The resulting conditioned serum contains elevated levels of various anti-inflammatory cytokines, such as IRAP, IL-4 and IL-10 [4, 7, 8]. Several investigators have reported effectiveness of IL-1Ra in a pilot human study when delivered by intraarticular injection in a canine model of OA $[9,10]$. After the initial skepticism, the positive outcome of an animal model and of recent prospective randomized controlled double-blind trials have provided the first evidence demonstrating that ACS is more effective in human samples than placebo and/or HA for the treatment of knee OA [4, 11-14].

The present study was a retrospective study aiming to determine the effect of ACS on OA; we made this analysis by injecting it to symmetrically involved knee.

\section{Material and methods}

With written informed patient consent, 33 (19 females, 14 males) patients not older than 70 years and with 66 knees were included in the study. Data collection and treatment took place at a single institution. The study was conducted in accordance with the Declaration of Helsinki. Approval for our study was obtained from the institutional review board. This study was based on a retrospective evaluation of one year followup findings of patients treated for osteoarthritis.

\section{Patient selection}

All patients presented to orthopedic outpatient clinic with bilateral knee pain score equal or more than 4 points of $0-10$ Visual Analog Scale (VAS) on the day of the examination. Patients were included to the study to have radiological verified bilateral grade 2-3 OA of the knee according to KellgrenLawrence classification [15]. All patients in this study had dissatisfaction with previous attempts at conservative treatment including non-steroidal anti-inflammatory drugs.
No patient dropped out or underwent surgery while enrolled in the study. Secondary arthritis, grade IV OA, systemic or inflammatory joint diseases, a history of a crystalline arthropathy, clinically relevant hematologic or abnormal clinical chemistry values, bone cancer, and metastasis or tumor-like lesions in immediate proximity to the treated joint, joint instability, intra-articular corticosteroid injection within the previous 6 months, history of diabetes mellitus, recent history of trauma to the knee and BMI $(\mathrm{kg} / \mathrm{m} 2)$ greater than 30 were the exclusion criteria. Patients were also excluded if they had contraindication to injection, such as infection, anticoagulation therapy, allergy or hypersensitivity, to any of the study medications. Patients using systemic corticosteroids were also excluded. Patients who had a VAS difference of more than 2 points between their knees were excluded from the study.

\section{Outcome Measurements}

All patients were analyzed for pain with the visual analog scale (VAS), Knee Injury and Osteoarthritis Score (KOOS) and Knee Society Score (KSS) before the administration of the first injection (pre-treatment) and again 1 year after the last injection (post-treatment). VAS was used to measure knee pain during the last week at rest and during daily activities. No pain was graded 0 and maximal pain was graded 10 on a $100-\mathrm{mm}$ scale. KOOS is a specific scale used in evaluating knee functions and knee-related quality of life. It is composed of five subscales as pain, patient's perception for other symptoms, daily life, sports and recreational activities. Scoring ranges between 0 and 100. 0 indicates abnormally high level of knee problems, while 100 indicates a healthy knee with no problems [16]. KSS includes three main constructs: pain, knee stability, and range of motion (ROM). Of the maximum 100 points, a possible 50 points are assigned to pain, 25 points to stability, and 25 points for ROM [17].

\section{ACS preparation}

To produce ACS, $50 \mathrm{~mL}$ of whole blood were taken from each patient using a special syringe with increased internal surface area; glass beads in the syringes increase the nonpyrogenic surface area and induce the dose-dependent production of IRAP (among others) by white blood cells in whole blood incubated at $37^{\circ} \mathrm{C}$. After incubation, the blood-filled syringes were centrifuged, and the serum supernatant was filtered (0.22 mm; Millipore, Carrigtwohill, Co. Cork, Ireland) and aliquoted into $6-8.2 \mathrm{~mL}$ portions. The aliquots were stored at $-20^{\circ} \mathrm{C}$ until use. A randomization procedure was followed to assign each compound to the right or the left knee.

\section{Administration of injection}

One orthopedic surgeon in one center applied all the injections. Patients were placed in sitting position with 90 degrees of knee flexion. Lateral approach to the knee was selected. The skin of the injection site was cleaned with povidone-iodine solution. No anesthetic was administered before injection. ACS was injected twice a week for a total of 6 times in both knee joints for 3 weeks. The patient was sent home after injection. Limited movement was allowed for 24 hours, and resting was recommended in case of pain. The patient was recommended not to receive NSAIDs nor to apply local ice for a week after injection in order not to reduce the efficacy of ACS. In addition, an exercise program was given to the patients, and performing normal daily activities when tolerable was recommended.

Another surgeon who was not aware of the study design performed the clinical evaluation. Clinical data were $\mathrm{P}$ a g e / S a y f a 95 
retrospectively collected from the patients' files and reported on a case report form before analysis. Patients underwent clinical evaluation before the injection and at the 1st year follow-up. VAS, KOOS and KSS scores were compared before the treatment and at the 1-year follow-up. The possible complications and side effects were also evaluated in each visit.

\section{Statistical Analysis}

Statistical analysis was performed using NCSS (Number Cruncher Statistical System) 2007 (Kaysville, Utah, USA). Descriptive statistics are expressed as number and percentage for categorical variables and as mean, standard deviation, median, minimum and maximum for numerical variables. . Paired Samples T-Test was used to compare KOSS and KSS scores before the treatment and at the 1-year follow-up. Non-parametric Wilcoxon Signed Ranks Test was used to compare VAS scores before the treatment and at the 1-year follow-up. $\mathrm{p}<0.01$ was considered statistically significant.

\section{Results}

The present study comprised 33 patients (19 females, 14 males) with 66 knees and a mean age of 57.6 \pm 8.21 (range: 41 70); general characteristics of the patients are demonstrated in Table 1. Before the first admission, the mean VAS score was $7.36 \pm 0.93$ (range: 5-9). After treatment at the 1-year follow-up time the mean VAS score was $3.27 \pm 1.23$ (range: 1-6). The change in VAS scores before and after treatment was statistically significant. Treatment with ACS consistently showed significant decrease in VAS $(\mathrm{p}<0.01)$ (Figure 1, Table 2).

Table 1. Demographic changes of patients

\begin{tabular}{llcc} 
& & Range & Mean \pm SD \\
\hline \multirow{3}{*}{ Age (year) } & & & \\
\multirow{3}{*}{ Gender } & $41-70$ & $57.66 \pm 8.21$ \\
& Female & $\mathrm{n}$ & $\%$ \\
& Male & 19 & 57.6 \\
\hline
\end{tabular}

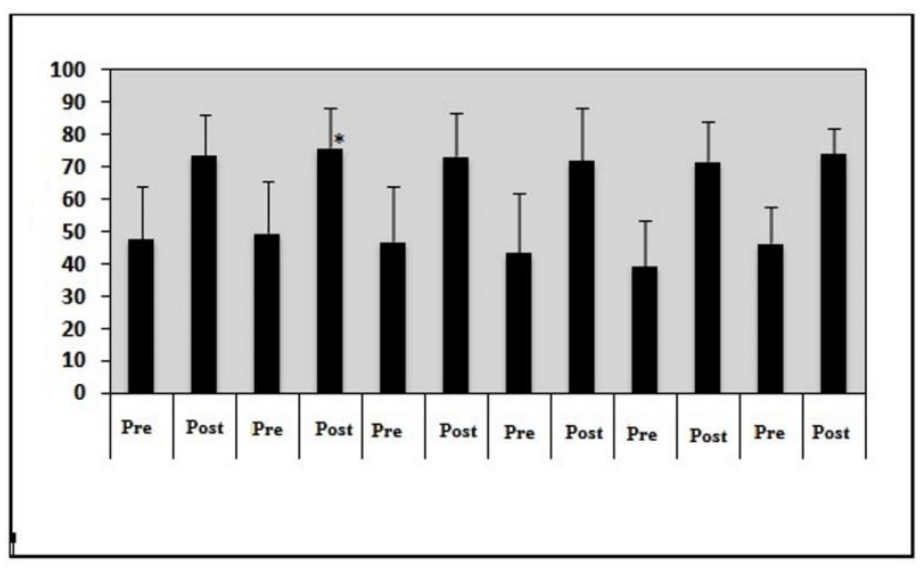

Figure 1. Before the treatment and at the 1-year follow-up of KOSS changes.

Pre-treatment and 1-year follow-up values of KOOS were $42.39 \pm 13.38$ (range: $21-65$ ) and $72.36 \pm 8.81$ (range: 54-92), respectively. ACS resulted in significantly greater improvement over the 1-year period bilaterally. When asked to rate their health in retrospect using the test, the patients reported a significant improvement in KOOS (sub-scores and total) 1 year after ACS treatment $(\mathrm{p}<0.01)$. Patients rated their initial health (all outcomes of KOSS) as lower than how they had rated it before the actual ACS treatment (Figure 1, Table 2).
By the end of the study, there was a significant improvement in the KSS over time. Pre-treatment and 1-year follow-up values of KSS were $42.79 \pm 10.26$ (range: 14-61) and $70.61 \pm 9.32$ (range: 49-84), respectively. Increase in KSS score from baseline to post-treatment 1 year was significant $(\mathrm{p}<0.01)$ (Figure 1, Table 2).

Table 2. Before the treatment and at the 1-year follow-up scores of the patients.

\begin{tabular}{llccc}
\hline & & Min-Max & Mean \pm SD & $\mathrm{p}$ \\
\hline KOOS stiffness & Before & $18-78$ & $44.67 \pm 18.09$ & 0.001 \\
& 1 year & $39-100$ & $72.85 \pm 13.35$ & \\
\hline KOOS pain & Before & $17-75$ & $45.30 \pm 14.90$ & 0.001 \\
& 1 year & $56-94$ & $74.21 \pm 10.36$ & \\
\hline KOOS function & Before & $18-87$ & $44.30 \pm 16.80$ & 0.001 \\
daily & 1 year & $53-95$ & $72.82 \pm 10.20$ & \\
\hline KOOS function & Before & $10-65$ & $31.82 \pm 14.94$ & 0.001 \\
activity & 1 year & $30-85$ & $66.15 \pm 13.39$ & \\
\hline KOOS life quality & Before & $12-75$ & $34.21 \pm 13.96$ & 0.001 \\
& 1 year & $56-92$ & $72.85 \pm 10.17$ & \\
\hline KOOS total & Before & $21-65$ & $42.39 \pm 13.38$ & 0.001 \\
& 1 year & $54-92$ & $72.36 \pm 8.81$ & \\
\hline VAS & Before & $5-9$ & $7.36 \pm 0.93$ & 0.001 \\
& 1 year & $1-6$ & $3.27 \pm 1.23$ & \\
\hline KSS & Before & $14-61$ & $42.79 \pm 10.26$ & 0.001 \\
& 1 year & $49-84$ & $70.61 \pm 9.32$ & \\
\hline
\end{tabular}

KOOS: Knee Injury and Osteoarthritis Score, VAS: Visual Analog Scale, KSS:Knee Society Score.

No intraarticular injection-related major complications such as infection, deep venous thrombosis, muscular atrophy was detected in any of the patients over the course of the treatments. We had no complication after injections.

\section{Discussion}

$\mathrm{OA}$ is accompanied by a number of mechanical and biologic dysfunctions within the joint, the central pathologic feature being the destruction of hyaline cartilage. Of the catabolic cytokines identified in osteoarthritic joints, IL-1, the most potent known mediator of cartilage loss [16-18], appears pivotal. The naturally occurring inhibitor of IL-1, the IL-1 receptor antagonist (IL-1Ra), could potentially limit the intraarticular actions of IL-1 and thereby control the disease process $[19,20]$.

IL1b is a pivotal mediator of many inflammatory and regenerative diseases, including OA, rheumatoid arthritis (RA) and spinal disorders. Strategies for inhibiting the biological activities of IL-1b include the use of the recombinant IL-1 receptor agonist, soluble forms of IL-1 receptors and antiinflammatory cytokines such as IL-4, IL-10 and IL-13, which inhibit the synthesis of IL-1 and/or increase the synthesis of IL1Ra. A biologic therapeutic preparation known as ACS has been developed and used clinically in orthopedic patients suffering from OA, RA and spinal disorders. ACS is prepared from peripheral whole blood. Briefly, blood is drawn into a syringe containing treated glass beads with $\mathrm{CrSO} 4$ to initiate monocyte activation [21, 22].

ACS was developed in the mid-1990s in an attempt to generate an injectable material enriched in endogenous IL-1 Ra as a novel therapeutic for OA. Meijer et al. noted that exposure of blood to glass beads elicits a vigorous and rapid increase in the synthesis of several anti-inflammatory cytokines, including IL1Ra. This observation is the basis for producing ACS, which is injected into the affected joint in a series of six intra-articular injections given twice a week for 3 weeks. This therapy is currently available for humans in several countries, and its use is even more widespread for equine OA, where ACS considerably 
improves clinical lameness in horses and may protect cartilage from degradation [23]. In our study, treatment with ACS produced a rapid decline in pain, accompanied by a large improvement in ROM. These results suggest that ACS is a valid option for the treatment of OA.

Injections of intra-articular therapies directly into the joint evade conservative obstacles to joint entry, rise bioavailability and minor systemic toxicity. Current progresses in osteoarthritis management have designed better diversity of treatment approaches. Based on novel opinions, an innovative therapy by ACS from the whole blood was settled. The inoculation of ACS into tissues has revealed clinical efficacy for the treatment of osteoarthritis and muscle injuries [6]. Our data show that ACS is safe and has a therapeutic effect on the major clinical parameters of painful knee OA. ACS resulted in significantly greater improvement over the 1-year period. Furthermore, patients treated with ACS consistently showed significantly higher improvements in terms of the pre-treatment parameters. Remarkably, the therapeutic effect persists for at least 1 year.

The ACS production process has been shown to reproducibly elevate IL-1Ra and other factors, although the mechanisms by which the effects are mediated are not fully understood [22, 24]. The multitude of synergistic and active therapeutic molecules may explain the observed clinical effect, but its long-term persistence is more difficult to explain. One possibility may be that the therapeutic molecules help reestablish a healthy joint homeostasis [25-29]. Given the favorable safety profile, reduction in pain and enhanced quality of life experienced by patients enrolled in this joint health program, ACS has the potential to offer an alternative, chondroprotective, natural, molecular approach to treating pain and functionality in patients with mild, moderate or severe knee osteoarthritis [29-31]. In terms of our experience, intra-articular injection of ACS in patients with painful knee OA has a safe profile and results in a strong clinical response. The data shows that ACS represents an effective and well-tolerated alternative to the currently predominant treatments of OA.

In summary, based on our clinical trial results, intraarticular ACS reduces pain and increases function and mobility for up to one year. It can be considered as clinically safe because of its autologous origin. No clinically serious side effects were observed in the ACS group during the observation period.

We have some limitations in our study. Firstly, the retrospective design of the study was the main limitation, and also we included patients with wide range of age distribution. However, we included similar grade of knee osteoarthritis and we treated our patients with same method. Our study may guide further studies when evaluating the effect of ACS in osteoarthritis treatment and relation the clinical outcomes.

In conclusion, the ACS is effective for the treatment of patients with low- to medium-grade painful knee OA. Although this study supports the use of ACS in mid-stage painful OA of the knee, we are aware of its shortcomings. We only treated patients with grade 2-3 OA of the knee according to KellgrenLawrence classification; so the results cannot necessarily be generalized to all OA patients.

\section{References}

1. Gupta S, Hawker GA, Laporte A, Croxford R, Coyte PC. The economic burden of disabling hip and knee osteoarthritis (OA) from the perspective of individuals living with this condition. Rheumatology (Oxford). 2005;44:1531-7.

2. Peat G, McCarney R, Croft P. Knee pain and osteoarthritis in older adults: a review of community burden and current use of primary health care. Ann Rheum Dis. 2001;60:91-7.
3. Michael JW, Schlüter-Brust KU, Eysel P. The epidemiology, etiology, diagnosis, and treatment of osteoarthritis of the knee. Dtsch Arztebl Int. 2010;107:152-62.

4. Baltzer A, Moser C, Jansen S, Krauspe R. Autologous conditioned serum (Orthokine) is an effective treatment for knee osteoarthritis. Osteoarthritis Cartilage. 2009;17:152-60.

5. Frisbie DD, Ghivizzani SC, Robbins PD, Evans CH, Mcllwraith CW. Treatment of experimental equine osteoarthritis by in vivo delivery of the equine interleukin-1 receptor antagonist gene. Gene Ther 2002;9:12-20.

6. Fotouhi A, Maleki A, Dolati S, Aghebati-Maleki A, Aghebati-Maleki L. Platelet rich plasma, stromal vascular fraction and autologous conditioned serum in treatment of knee osteoarthritis. Biomed Pharmacother. 2018;104:652-60.

7. Fernandes J, Tardif G, Martel-Pelletier J, Lascau-Coman V, Dupuis M, Moldovan F. et al. In vivo transfer of interleukin-1 receptor antagonist gene in osteoarthritic rabbit knee joints: prevention of osteoarthritis progression. Am J Pathol. 1999;154:1159-69.

8. de Ascurra JL, Ehrle A, Einspanier R, Lischer C. Influence of Incubation Time and Incubation Tube on the Cytokine and Growth Factor Concentrations of Autologous Conditioned Serum in Horses. J Equine Vet Sci. 2019;75:30-4.

9. Linardi RL, Dodson ME, Moss KL, King WJ, Ortved KF. The effect of autologous protein solution on the inflammatory cascade in stimulated equine chondrocytes. Front Vet Sci. 2019;6:64.

10. Rutgers M, Saris DBF, Dhert WJA, Creemers LB. Cytokine profile of autologous conditioned serum for treatment of osteoarthritis, in vitro effects on cartilage metabolism and intra-articular levels after injection. Arthritis Res Ther. 2010;12:R114.

11. Chevalier X, Giraudeau B, Conrozier T, Marliere J, Kiefer P, Goupille P. Safety study of intraarticular injection of interleukin 1 receptor antagonist in patients with painful knee osteoarthritis: a multicenter study. J Rheumatol. 2005;32:1317-23.

12. Burmester GR, Grifka J. Revision of the recommendations of the Commission on the Pharmacotherapy of the German Society for Rheumatology. Z Rheumatol. 2007;66:83-4.

13. Frisbie D, Kawcak C, Werpy N, Park RD, McIlwraith CW. Clinical, biochemical, and histologic effects of intra-articular administration of autologous conditioned serum in horses with experimentally induced osteoarthritis. Am J Vet Res. 2007;68:290-6.

14. Yang K, Raijmakers NJ, van Arkel ER, Caron JJ, Rijk PC, Willems WJ, et al. Autologous interleukin-1 receptor antagonist improves function and symptoms in osteoarthritis when compared to placebo in a prospective randomized controlled trial. Osteoarthritis Cartilage. 2008;16:498-505.

15. Kellgren JH, Lawrence JS. Radiological assessment of osteoarthrosis. Ann Rheum Dis. 1957;16:494-501.

16. Roos EM, Roos PH, Lohmander LS, Ekdahl C, Beynnon BD. Knee injury and Osteoarthritis Outcome Score (KOOS): Development of a self-administered outcome measure. J Orthop Sports Phys Ther 1998;78:88-96.

17. Insall JN, Dorr LD, Scott RD, Scott WN. Rationale of the Knee Society clinical rating system. Clin Orthop Relat Res. 1989;248:13-4

18. Freyd M. The graphic rating scale. J Educ Psychol. 1923;14:83-102.

19. Goldring MB. Osteoarthritis and cartilage: the role of cytokines. Curr Rheumatol Rep. 2000;2:459-65.

20. Goldring SR, Goldring MB. The role of cytokines in cartilage matrix degeneration in osteoarthritis. Clin Orthop Relat Res. 2004;427:27-36.

21. Fernandes JC, Martel-Pelletier J, Pelletier JP. The role of cytokines in osteoarthritis pathophysiology. Biorheology. 2002;39:237-46.

22. Arend WP, Malyak M, Guthridge CJ, Gabay C. Interleukin-1 receptor antagonist: role in biology. Annu Rev Immunol. 1998;16:27-55.

23. Dinarello CA. Interleukin-1 and interleukin-1 antagonism. Blood. 1991;77:1627-52.

24. Dinarello CA. The role of the interleukin-1-receptor antagonist in blocking inflammation mediated by interleukin-1. N Engl J Med. 2000;343:732-4.

25. Zarringam D, Bekkers J E, Saris DB. Long-term effect of injection treatment for osteoarthritis in the knee by orthokin autologous conditioned serum. Cartilage. 2018;9:140-5.

26. Arend WP, Leung DY. IgG induction of IL-1 receptor antagonist production by human monocytes. Immunol Rev.1994;139:71-8.

27. Frisbie DD, Kawcak CE, Werpy NM, Park RD, McIIwraith CW Clinical, biochemical, and histologic effects of intra-articular administration of autologous conditioned serum in horses with experimentally induced osteoarthritis. Am J Vet Res. 2007;68:290-6.

28. Wright-Carpenter T, Opolon P, Appell HJ, Meijer H, Wehling P, Mir LM. Treatment of muscle injuries by local administration of autologous 
conditioned serum: animal experiments using a muscle contusion model. Int J Sports Med. 2004;25:582-7.

29. Yang KG, Raijmakers NJ, Van Arkel ER, Caron JJ, Rijk PC, Willems WJ, et al. Autologous interleukin-1 receptor antagonist improves function and symptoms in osteoarthritis when compared to placebo in a prospective randomized controlled trial. Osteoarthritis Cartilage. 2008;16:498-505.

30. Damjanov N, Barac B, Colic J, Stevanovic V, Zekovic A, Tulic G. The efficacy and safety of autologous conditioned serum (ACS) injections compared with betamethasone and placebo injections in the treatment of chronic shoulder joint pain due to supraspinatus tendinopathy: a prospective, randomized, double-blind, controlled study. Med Ultrason. 2018;20:335-41.

31. von Wehren L, Pokorny K, Blanke F, Sailer J, Majewski M. Injection with autologous conditioned serum has better clinical results than eccentric training for chronic Achilles tendinopathy. Knee Surg Sports Traumatol Arthrosc. 2019; Mar 21. doi: 10.1007/s00167-019-05465-8.

32. Tassara M, De Ponti A, Barzizza L, Zambelli M, Parisi C, Milani R, et al. Autologous conditioned serum (ACS) for intra-articular treatment in Osteoarthritis: Retrospective report of 28 cases. Transfus Apher Sci. 2018;57:573-7.

33. Barreto A, Braun R. A new treatment for knee osteoarthritis: Clinical evidence for the efficacy of Arthrokinex ${ }^{\mathrm{TM}}$ autologous conditioned serum. J Orthop. 2016;14:4-9. 